\title{
Pervasiveness of endophytic fungal diversity in Anisomeles malabarica from Aliyar, Western Ghats, South India
}

\author{
Jayanthi $G^{1,2}$, Karthikeyan $K^{1}$ and Muthumary $\mathbf{J}^{2}$ \\ ${ }^{1}$ Division of Coastal and Marine Ecology, Gujarat Institute of Desert Ecology, Mundra Road, Bhuj, Dist: Kachchh, \\ Gujarat-370001, India. \\ ${ }^{2}$ Centre for Advanced Studies in Botany, University of Madras, Maraimalai campus, Chennai - 600 025, India.
}

Jayanthi G, Karthikeyan K, Muthumary J 2014 - Pervasiveness of endophytic fungal diversity in Anisomeles malabarica from Aliyar, Western Ghats, South India. Mycosphere 5(6), 830-840, Doi 10.5943/mycosphere/5/6/13

\begin{abstract}
A total of 616 fungal isolates were obtained from 1600 segments of leaves and stems of the medicinal plant Anisomeles malabarica during four seasons (2009-2010). Fourteen different morphospecies were isolated: Botryodiplodia theobromae, Colletotrichum dematium, Pestalotiopsis microspora, Phoma betae, Phomopsis arnoldiae, Phomopsis stipata, Phomopsis sp., Phomopsis tersa, Phyllosticta murnadensis, Septoria sp., Penicillium sp., Nigrospora sp. and sterile forms. Phomopsis spp. was the most dominant and frequently isolated taxon. Colonization frequency (\%) differed significantly between the seasons. The total colonization frequency of endophytes during south-west monsoon comprised young leaves $6.6 \%$, mature leaves $15.7 \%$, young stems $3.6 \%$ and mature stems $13.4 \%$; north-east monsoon comprised young leaves $4.3 \%$, mature leaves $16 \%$, young stems $7 \%$ and mature stems $15.9 \%$; winter comprised young leaves $14 \%$, mature leaves $21.7 \%$, young stems $12.5 \%$ and mature stems $17.1 \%$; summer comprised young leaves $1.2 \%$, mature leaves $4.4 \%$, young stems $0.9 \%$ and mature stems $2.6 \%$. The colonization rate was higher during the winter than in the monsoon and summer seasons. Moreover, the higher colonization frequency was found in mature leaves than in young leaves. The maximum relative percentage occurrence was coelomycetes $(97.91 \%)$ followed by agnomycetes $(1.33 \%)$ and hyphomycetes $(0.76 \%)$.
\end{abstract}

Key words - Anisomeles malabarica - diversity - endophytic fungi - total colonization frequency percentage - relative percentage occurrence

\section{Introduction}

Strobel (2003) noted that approximately 300,000 plant species growing in an unexplored area on the earth are host to one or more endophytes and the presence of biodiverse endophytes in huge number plays an important role in ecosystems with the greatest biodiversity in tropical and temperate rainforests (Strobel \& Daisy 2003). A single endophytic fungal species may form relationships with two related plant species, but demonstrate a preference for one particular host, and this phenomenon is categorized as host selectivity (Cohen 2004, 2006). Evidence of plantassociated microorganisms found in the fossilized tissues of stems and leaves has revealed that the symbiosis of endophyte-host most probably dates back to the emergence of vascular plants (Strobel 
2003). Zhang et al. (2006) found that the endophytes are detected in plants growing in tropical, subtropical, temperate, and boreal forests with the hosts ranging from herbaceous plants in various habitats, like arctic, alpine and xeric to mesic temperate and tropical forests.

Suryanarayanan et al. (2002) studied tropical forests in the Nilgiri Biosphere Reserve of the Western Ghats for endophyte assemblages based on host recurrence and spatial heterogeneity of their endophytes and concluded that the dry tropical forests had much less endophyte diversity compared to wet tropical forests. However, the study of endophytic fungal biodiversity is very meager. To date, only a few plants have been broadly investigated for their endophytic biodiversity and their probable to produce bioactive secondary metabolites. One of the important roles of endophytic fungi for nutrient recycling is to initiate the biological degradation of dead host-plant (Strobel 2002a). Medicinal plants are reported to harbour endophytes (Strobel 2002b), which in turn provide protection to their host from infectious agents and also provide adaptability to survive in adverse environmental conditions. Hence it is important to explore the endophyte diversity of medicinal plants. Many reports confirmed that endophytic fungi such as Pestalotiopsis spp., Pestalotia spp., Phomopsis spp., Phyllosticta spp., Melanconium spp., Colletotrichum spp., Phoma spp., Chaetomium spp., Botryodiplodia spp., Bartalinia spp. and Monochaetia spp. can produce medicinally important bioactive secondary metabolites (Firakova et al. 2007). Interestingly, more endophytic coelomycetous fungi have been reported than hyphyomycetes (Petrini 1986, Wang et al. 2000, Zhou et al. 2001, Yuan et al. 2006, Muthumary \& Sashirekha 2007). Jayanthi et al. (2011) isolated an endophytic Phomopsis sp. from Mesua ferrea which recorded antimicrobial activity against various human pathogens. The present study focused on endophytes from the medicinal plant Anisomeles malabarica (L.) R.Br., family Lamiaceae. It is used to treat for dyspepsia, fever, rheumatism, snakebite, epilepsy, hysteria, dementia, anorexia, dyspepsia, colic, flatulence, intestinal worms, intermittent fevers, arthritis and diarrhea.

\section{Materials \& Methods}

\section{Collection of plant samples}

Material of Anisomeles malabarica was collected from Azhiyar $\left(10.4739^{\circ} \mathrm{N}, 76.9728^{\circ} \mathrm{E}\right.$, located in Anamalai foothills of the Western Ghats), Pollachi Taluk, Coimbatore District, Tamil Nadu, India between May 2009 and April 2010. The samples were collected during different seasons viz., Summer (March-May), South-West Monsoon (June-August), North-East Monsoon (September-November) and Winter (December-February). Young stems (YS), mature stems (MS), young leaves (YL) and mature leaves (ML) were collected. The plant samples were gathered from their natural habitat, placed into sterile polythene bags and taken to the laboratory. The samples were processed within 24 h of collection (Fisher \& Petrini 1987).

\section{Isolation of endophytic fungi}

The samples were washed meticulously by running tap water. To eliminate the superfluous phylloplane fungal propagules adhering to the cuticle of the leaves, the samples were surface sterilized following the protocol described by Dobranic et al. (1995) with slight alterations. Four hundred segments (approx. $0.5 \mathrm{~cm}^{2}$ ) per different tissues (young stems and mature stems, young leaves and mature leaves) were taken for the study of fungal endophytes (Fisher et al. 1993, Dobranic et al. 1995). The inoculated Petri plates were left in a light chamber for 3-4 weeks (Bills \& Polishook 1992) at $23 \pm 2^{\circ} \mathrm{C}$. Fungal endophytes were maintained on PDA slants in a refrigerator.

\section{Preparation of semi-permanent slides}

Specimens with fruit bodies were sectioned with the help of a sterile scalpel blade. Based on the nature of the specimen, the selected sections $(10-15 \mu \mathrm{m})$ were placed in lactophenol, lactophenol cotton blue or modified Leifson's flagella stain and observed under a light microscope. For the preparation of semi-permanent slide, the slides were sealed with DPX mount. The vertical 


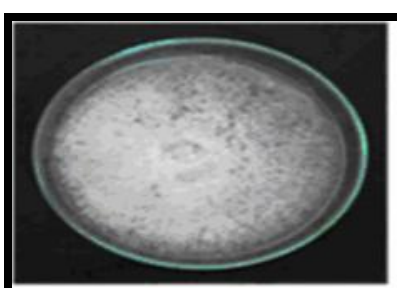

Phomopsisstipata

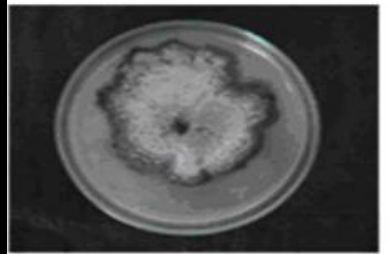

Phyllostiota mumadenis

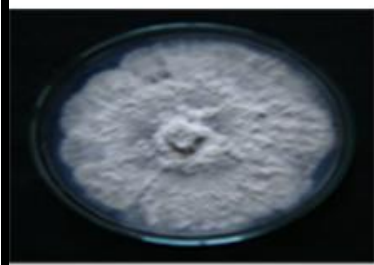

Septoria sp. 01

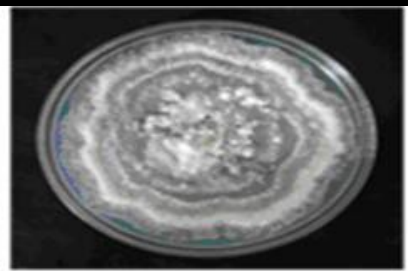

Phomopsiss. 17

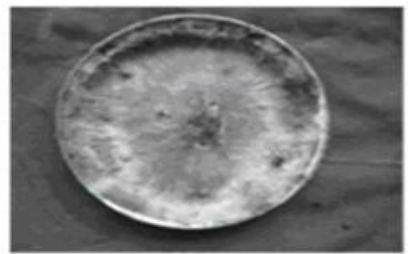

Botryodiplatia theobromar

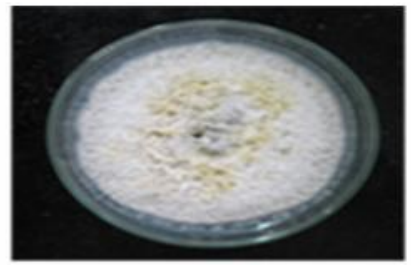

Pestalotiopsismicrospora

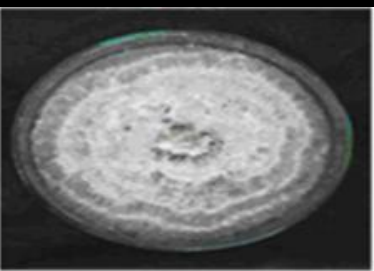

Phomopsis amoldae

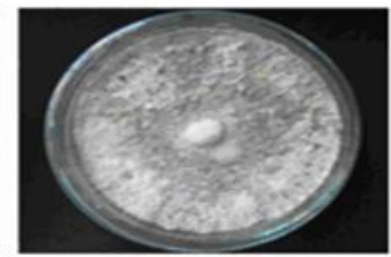

Phoma betae

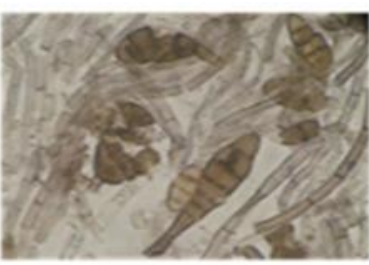

Altemaria sp. 01

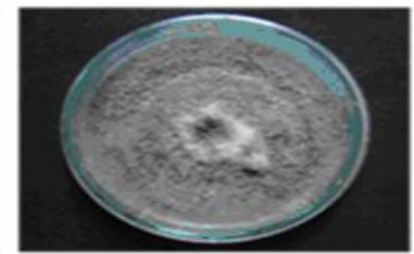

Colletorichum dematium

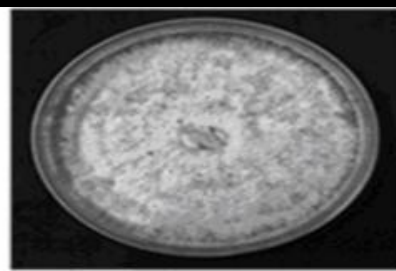

Phomopsistersa

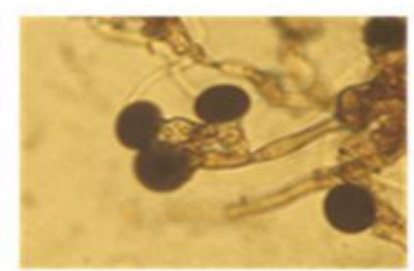

Nigrospora sp.01

Fig. 1 - Culture plates of endophytic fungi obtained from Anisomeles malabarica

sections of the conidiomata were taken to confirm the nature and position of the fructification and conidia in the distilled water was observed under microscope and then photographed.

\section{Identification and Data analysis}

The fungi were identified on the basis of the structure of the conidiomata, conidiogenous cells and conidia (Sutton 1973a, 1973b, 1980). The presence of appendages on the conidia is recognized as an important taxonomic criterion (Guba 1961, Ellis 1971, Onions et al. 1981, Nag Raj 1993) and the conidia were measured. Identification of coelomycetes was done by using standard manuals (Guba 1961, Sutton 1980, Nag Raj 1993).

\section{Colonization Frequency (CF \%)}

The colonization frequency for endophytic fungi in the leaves and stems was calculated by using the following formula (Hata \& Futai 1995).

$$
\mathrm{CF} \%=\frac{\text { No. of segments colonized by an endophytic sp. }}{\text { Total number of segments }} \times 100
$$

\section{Relative Percentage Occurrence (RPO \%) of each group of fungi}

Relative percentage occurrence of each group of fungi (viz., coelomycetes, hyphomycetes and agnomycetes) was calculated using the following formula,

$$
\text { RPO } \%=\frac{\text { Density of colonization of one group }}{\text { Total density of colonization of all groups }} \times 100
$$


Table 1 Colonization frequency percentage of endophytic fungi isolated from Anisomeles malabarica during different seasons (2009-2010)

\begin{tabular}{|c|c|c|c|c|c|c|c|c|c|c|c|c|c|c|c|c|c|}
\hline \multirow[t]{4}{*}{ S. No } & \multirow[t]{4}{*}{ Endophytes } & \multicolumn{16}{|c|}{ Colonization frequency of endophytes } \\
\hline & & \multirow{2}{*}{\multicolumn{4}{|c|}{$\frac{\text { South West monsoon }}{\text { (June-Sep) }}$}} & \multirow{2}{*}{\multicolumn{4}{|c|}{$\frac{\text { North East monsoon }}{\text { (Oct-Nov) }}$}} & \multirow{2}{*}{\multicolumn{4}{|c|}{$\begin{array}{c}\text { Winter season } \\
\text { (Dec-Feb) } \\
\end{array}$}} & \multirow{2}{*}{\multicolumn{4}{|c|}{$\frac{\text { Summer season }}{\text { (Mar-May) }}$}} \\
\hline & & & & & & & & & & & & & & & & & \\
\hline & & $\mathbf{Y L}$ & ML & $\mathbf{Y S}$ & MS & $\overline{Y L}$ & ML & $\mathbf{Y S}$ & MS & $\mathbf{Y L}$ & ML & $\mathbf{Y S}$ & MS & $\mathbf{Y L}$ & ML & YS & MS \\
\hline \multicolumn{18}{|c|}{ COELOMYCETES } \\
\hline 1 & Botryodiplodia theobromae & - & - & - & - & 2.0 & 3.0 & 1.0 & 2.2 & - & 0.8 & - & 0.5 & 0.3 & 0.3 & - & - \\
\hline 2 & Colletotrichum dematium & 3.0 & 3.8 & 1.3 & 2.2 & - & 1.3 & - & 0.5 & - & - & - & - & - & 0.5 & - & 0.3 \\
\hline 3 & Pestalotiopsis microspora & 0.8 & 1.3 & - & 0.5 & - & 0.8 & - & 2.0 & 0.8 & 2.0 & 1.3 & 1.8 & 0.3 & 0.3 & - & - \\
\hline 4 & Phoma betae & 1.5 & 2.2 & 1.0 & 2.0 & - & - & - & - & - & - & - & - & - & 1.3 & - & 0.3 \\
\hline 5 & Phomopsis arnoldiae & - & 1.8 & - & 2.2 & 0.5 & 1.5 & 1.0 & 1.3 & 2.0 & 2.2 & 1.3 & 1.8 & - & 0.5 & 0.3 & 0.3 \\
\hline 6 & Phomopsis stipata & 0.3 & 1.3 & - & - & - & 3.8 & 1.5 & 3.0 & 3.0 & 3.8 & 3.5 & 3.8 & 0.3 & 0.3 & 0.3 & 0.3 \\
\hline 7 & Phomopsis sp. 17 & - & 1.0 & - & 1.5 & 1.8 & 3.5 & 2.2 & 3.8 & 4.5 & 5.0 & 2.5 & 3.0 & - & 0.3 & - & 0.3 \\
\hline 8 & Phomopsis tersa & - & 0.8 & 0.5 & 1.3 & - & - & 1.3 & 2.8 & 2.2 & 2.8 & 1.8 & 2.5 & 0.3 & 0.3 & - & - \\
\hline 9 & Phyllosticta murnadensis & 0.5 & 1.5 & 0.5 & 1.3 & - & 0.5 & - & - & 0.5 & 1.8 & 0.8 & 1.3 & - & - & 0.3 & 0.5 \\
\hline \multicolumn{17}{|c|}{ HYPHOMYCETES } & 0.3 \\
\hline 1 & Penicillium sp.01 & - & - & - & 0.3 & - & 0.3 & - & - & - & - & - & - & - & - & - & - \\
\hline 2 & Nigrospora sp.01 & - & - & - & - & - & - & - & - & - & 0.3 & - & 0.3 & - & - & - & - \\
\hline \multicolumn{18}{|c|}{ AGNOMYCETES } \\
\hline 1 & Sterile form 01 & - & - & 0.3 & 0.3 & - & - & - & - & - & - & - & - & - & 0.3 & - & 0.3 \\
\hline 2 & Sterile form 02 & - & - & - & - & - & 0.3 & - & 0.3 & - & - & - & 0.3 & - & - & - & - \\
\hline \multirow{2}{*}{\multicolumn{2}{|c|}{$\begin{array}{l}\text { No. of species recorded } \\
\text { Total no. of isolates observed }\end{array}$}} & 6 & 9 & 5 & 10 & 3 & 10 & 5 & 8 & 7 & 9 & 7 & 10 & 4 & 10 & 3 & 8 \\
\hline & & 26 & 62 & 14 & 53 & 17 & 63 & 28 & 63 & 56 & 86 & 49 & 67 & 4 & 16 & 3 & 9 \\
\hline \multirow{2}{*}{\multicolumn{2}{|c|}{$\begin{array}{l}\text { Total CF\% per season } \\
\text { Total }\end{array}$}} & 6.6 & 15.7 & 3.6 & 13.4 & 4.3 & 16 & 6.7 & 15.9 & 14 & 21.7 & 12.5 & 17.1 & 1.2 & 4.4 & 0.9 & 2.6 \\
\hline & & \multicolumn{4}{|c|}{39.3} & \multicolumn{4}{|c|}{42.9} & \multicolumn{4}{|c|}{65.3} & \multicolumn{4}{|c|}{9.1} \\
\hline
\end{tabular}

YL-young leaf; ML-mature leaf; YS-young stem; MS-mature stem; CF\%-Colony frequency percentage 


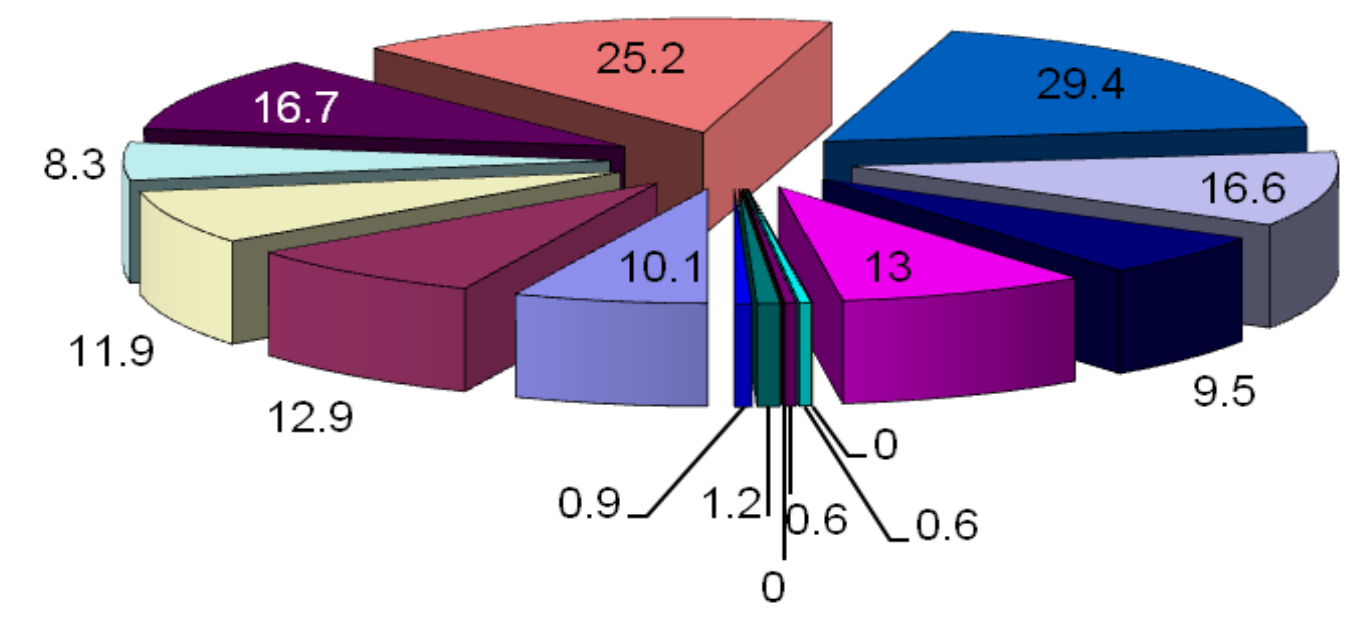

\begin{tabular}{|ll|}
\hline$\square 1$ Botryodiplodia theobromae & $\square 2$ Colletotrichum dematium \\
$\square 3$ Pestalotiopsis microspora & $\square 4$ Phoma betae \\
$\square 5$ Phomopsis arnoldiae & $\square 6$ Phomopsis stipata \\
$\square 7$ Phomopsis sp. 17 & $\square 8$ Phomopsis tersa \\
$\square 9$ Phyllosticta murnadensis & $\square 10$ Septoria sp. 01 \\
$\square 11$ Penicillium sp.01 & $\square 12$ Nigrospora sp.01 \\
$\square 13$ Sterile form 01 & $\square 14$ Sterile form 02 \\
\hline
\end{tabular}

Fig.2 - Total colonization frequency percentage per year in Anisomeles malabarica

\section{Results}

A total of 155, 171, 258 and 32 fungal isolates (i.e., 616 isolates) from 1600 segments (approx. $0.5 \mathrm{~cm}^{2}$ ) of young leaves, mature leaves, young stems and mature stems were isolated during 2009-2010 and their colonization frequencies and relative percentage occurrence were shown in Table. 1. The endophytic fungi isolated are represented in figure 1. Coelomycetes were found to be the dominant group (Fig. 2).

\section{South west monsoon}

A total of 155 isolates, i.e. young leaves (26), mature leaves (62), young stem (14) and mature stem (53) were isolated from 400 segments. Eleven different morphospecies were isolated and identified from leaves and stems. The total colonization frequency of endophytes of young leaves $6.6 \%$, mature leaves $15.7 \%$, young stem $3.6 \%$ and mature stem $13.4 \%$ were recorded. The most frequently isolated genera were Phomopsis (Phomopsis arnoldiae, Phomopsis stipata, Phomopsis sp. 17 and Phomopsis tersa). Single species of Colletotrichum dematium, Pestalotiopsis microspora, Phoma betae, Phyllosticta murnadensis and Septoria sp. 01 of coelomycetes were also recorded, followed by the sterile form 01 (agnomycetes) and Penicillium sp.01 (hyphomycetes).

\section{North east monsoon}

A total of 171 isolates, i.e. young leaves (17), mature leaves (63), young stem (28) and mature stem (63) were isolated from 400 segments. Eleven different morphospecies were isolated and identified from leaves and stems. The total colonization frequency of endophytes of young leaves $4.3 \%$, mature leaves $16 \%$, young stem $7 \%$ and mature stem $15.9 \%$ were recorded. The most frequently isolated genera were Phomopsis (Phomopsis arnoldiae, Phomopsis stipata, Phomopsis sp. 17 and Phomopsis tersa) and single species of Botryodiplodia theobromae, Colletotrichum dematium, Pestalotiopsis microspora, Phyllosticta murnadensis and Septoria sp.01 of coelomycetes were also recorded, followed by the sterile form 02 (agnomycetes) and Penicillium sp. 01 (hyphomycetes). 


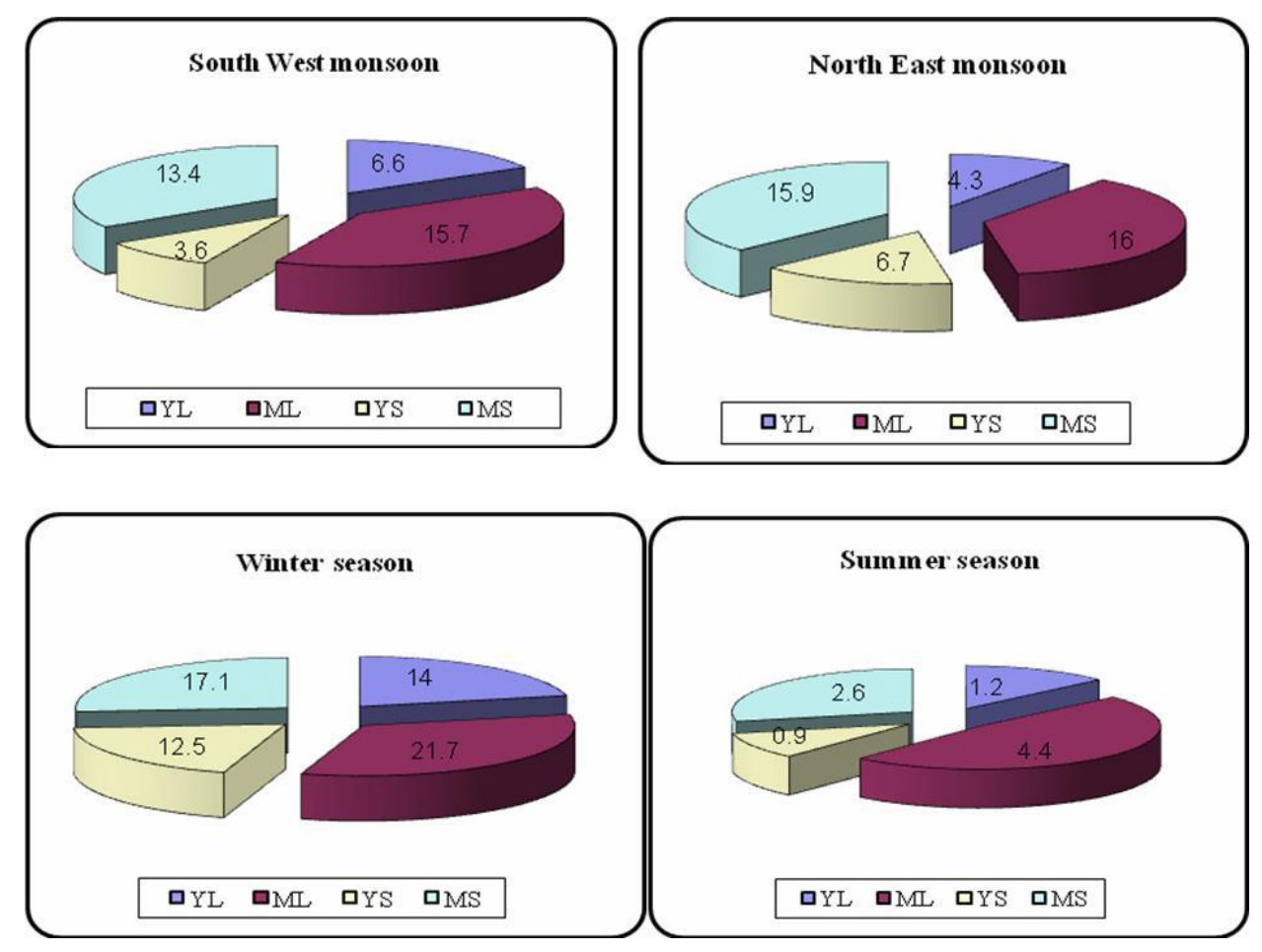

Fig.3 - Distribution of endophytic mycobiota in leaves and stems of Anisomeles malabarica

\section{Winter season}

A total of 258 isolate, i.e. young leaves (56), mature leaves (86), young stem (49) and mature stem (67) were isolated from 400 segments. Ten different morphospecies were isolated and identified from leaves and stems. The total colonization frequency of endophytes of young leaves $14 \%$, mature leaves $21.7 \%$, young stem $12.5 \%$ and mature stem $17.1 \%$ were recorded. The most frequently isolated genera were Phomopsis (Phomopsis arnoldiae, Phomopsis stipata, Phomopsis sp. 17 and Phomopsis tersa) and single species of Botryodiplodia theobromae, Pestalotiopsis microspora, Phyllosticta murnadensis and Septoria sp.01 of coelomycetes were also recorded, followed by Nigrospora sp. 01 (hyphomycetes) and sterile form 02 (agnomycetes).

\section{Summer season}

A total of 32 isolates i.e. young leaves (4), mature leaves (16), young stem (3) and mature stem (9) were isolated from 400 segments. Eleven different morphospecies were isolated and identified from leaves and stems. The total colonization frequency of endophytes of young leaves $1.2 \%$, mature leaves $4.4 \%$, young stem $0.9 \%$ and mature stem $2.6 \%$ were recorded. The most frequently isolated genera were Phomopsis (Phomopsis arnoldiae, Phomopsis stipata, Phomopsis sp. 17 and Phomopsis tersa) and single species of Botryodiplodia theobromae, Colletotrichum dematium, Pestalotiopsis microspora, Phoma betae, Phyllosticta murnadensis and Septoria sp. 01 of coelomycetes were also recorded, followed by the sterile form 01 (agnomycetes).

\section{Discussion}

The study of endophytes of tropical plants has received much attention because endophytes are believed to be a potential source of biologically active novel compounds (Dreyfuss \& Petrini 1984, Hyde 2001). Medicinal plants of Western Ghats of India (a hot spot of global biodiversity) are reported to have a diverse community of endophytic fungi (Raviraja 2005, Krishnamurthy et al. 2008). Few studies on the endophytic fungi of the plants was carried out to probe the diversity of endophytic fungi and their seasonal colonization pattern in medicinal shrub species commonly used in the Malnad region, Western Ghats of Karnataka, Southern India (Krishnamurthy et al. 2008). Hence, in the present study, an unexplored area was chosen for probing endophytic fungi from unexplored medicinal plant Anisomeles malabarica. 


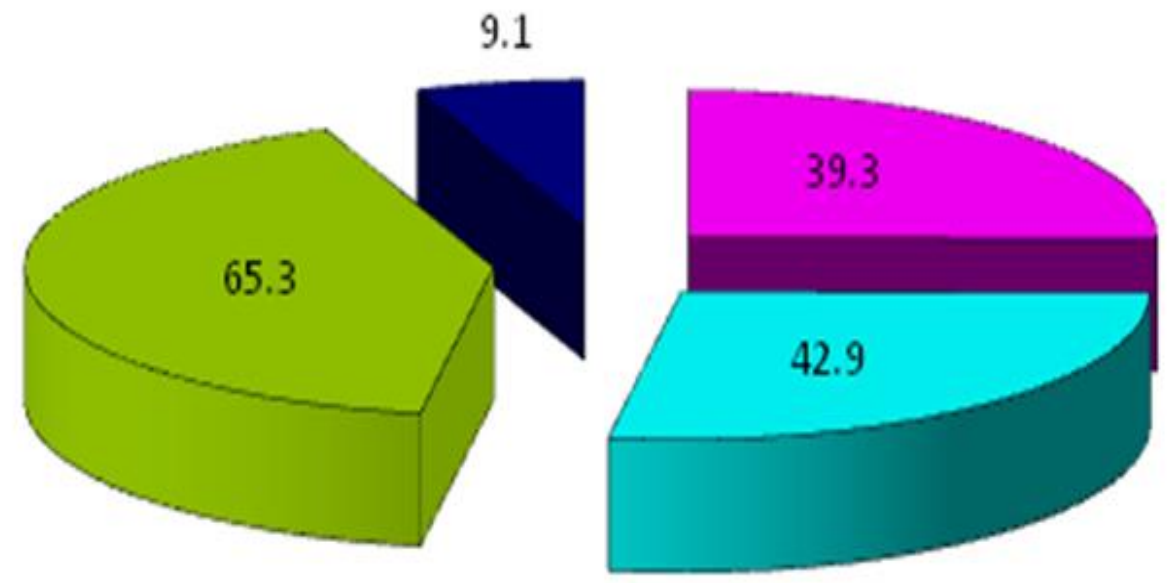

\section{QSWM QNEM QWS $\mathbf{Q S S}$}

Fig.4 - TCF percentage of endophytic mycobiota on different seasons in A. malabarica

SWM-South West Monsoon; NEM-North East Monsoon; WS-Winter Season; SS-Summer Season.

The increased incidence of endophytic taxa in the older leaves may be due to the increased time of exposure and hence increased accumulation of endophytic fungi from the environment. Older leaves also would have more time to accumulate transmitted colonizers that enter from the petioles (Baun et al. 2003, Oses et al. 2008). The leaves of different maturity showed different rates of colonization; young leaves had $3.33 \%$, mature leaves had $21.02 \%$. The stem, however, showed low percentage frequency of colonization of the endophytic fungi (Goveas et al. 2011). Correspondingly, in the present study, the leaves and stems of different maturity showed different rates of colonization. The result shows that the colonization of endophytic coelomycetes in Anisomeles malabarica was significantly higher in leaves than in the stem and also seasonal incidence of endophytes increases with the increasing age of the leaves and stem. Moreover, the highest colonization frequency was found in mature leaves than in the young leaves (Fig. 3) due to the difference in the time of exposure of endophytes. Alternaria sp., Nigrospora sp. and the sterile forms were found maximum in leaves rather than the stems. The present result also coincides with the findings of Huang et al. (2008), in which some endophytic fungi more frequently colonized the leaves, and other the stems. For example, more endophytic isolates of mycelia sterilia and Alternaria sp. were obtained from the leaves than from the stems.

Khan et al. (2007) found eight different species with $8.86 \%$ colonization frequency were isolated from Calotropis procera. In the present study, 14 different species were observed during South West monsoon, North East monsoon, summer season and winter season and the total colonization frequency was $39.3 \%, 42.9 \%, 65.3 \%$ and $9.1 \%$, which is slightly more than the above cited study. Thalavaipandian et al. (2011) stated that highest colonization frequency and greater diversity of endophytes was found in monsoon and winter than in summer season. The colonization frequency of endophytic fungi varied and differed significantly between the seasons. Similarly, in the present study, the colonization frequency of leaves and stem was significantly increased during monsoon and winter and decreased during summer season (Fig. 4).

The frequently isolated fungi such as Chaetomium globosum, Colletotrichum gloeosporioides, Phyllosticta spp., and Cladosporium spp. are generalist species which grow rapidly on culture medium (Frohlich \& Hyde 1999, Suryanarayanan et al. 2003, Krishnamurthy et al. 2008). The coelomycetes such as Phoma, Phomopsis and Phyllosticta are common endophytic fungi (Muller \& Hallaksela 1998, Wipornpan et al. 2001, Aveskamp et al. 2008), but are difficult to distinguish from one another due to their similarity in morphological characteristics (Shenoy et 


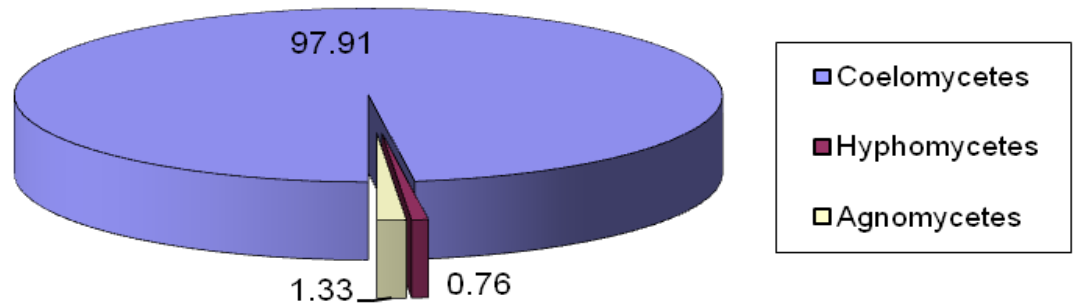

Fig.5 - Relative percentage occurrence of different group of fungi in A. malabarica

al. 2007). Species of Phomopsis are widespread plant pathogens and endophytes (Boddy \& Griffith 1989). Bussaban et al. (2001) stated that Colletotrichum "gloeosporioides", Glomerella spp., Xylariaceous fungi, and Phomopsis spp. were found to be dominant endophytes in Amomum siamense. Qi et al. (2012) reported that Alternaria sp., Neurospora sp., Phomopsis sp., and Phoma sp. were the dominant endophytes in Acer ginnala.

In the present study, the most frequently isolated genera were Phomopsis (Phomopsis arnoldiae, Phomopsis stipata, Phomopsis sp. 17 and Phomopsis tersa). Single species of Botryodiplodia theobroma, Colletotrichum dematium, Pestalotiopsis microspora, Phoma betae, Phyllosticta murnadensis and Septoria sp. 01 (Coelomycetes) were also recorded, followed by the sterile form 01 and 02 (Agnomycetes), Penicillium sp. 01 and Nigrospora sp. 01 (Hyphomycetes). Mycelia sterilia have been frequently isolated as endophyes from a wide range of tropical and temperate host plants (Suryanarayanan et al. 2004). Since the many sterile fungi do not sporulate in culture and due to the existence of non-culturable endophytes, the real number of endophytic species can be underestimated (Hyde \& Soytong 2007). In the current study two sterile forms were isolated. Chareprasert et al. (2006) found that Phomopsis was the most frequent endophytic fungus isolated from leaves, both young and adult, of Tectona grandis and Samanea saman Merr. Similarly, in the present study, Phomopsis spp. (Phomopsis arnoldiae, Phomopsis stipata, Phomopsis sp. 17 and Phomopsis tersa) were the most dominant and frequently isolated taxa as endophyte from four seasons during the year 2009-2010.

During the four seasons, fourteen different morphospecies were isolated and identified from leaves and stem. Botryodiplodia theobromae was not found in South-west monsoon season. Phoma betae was absent in North east monsoon and winter season. Colletotrichum dematium was absent in winter season. Hyphomycetes were absent in summer season. According to Kumar \& Hyde (2004), the vast genera of fungal endophytes were coelomycetes $(35 \%)$ followed by mycelia sterilia (23.6\%), hyphomycetes (15\%) and Zygomycetes (0.02\%). In the present study, the maximum RPO percentage was found in coelomycetes $(97.91 \%)$ followed by agnomycetes $(1.33 \%)$ and hyphomycetes $(0.76 \%)$ (Fig. 5).

\section{Acknowledgement}

The authors thank Dr. R. Rengasamy, Former Director, University of Madras for providing Laboratory facilities to conduct the Research work. The first author also thanks University Grants Commission, New Delhi for a Research Fellowship.

\section{References}

Aveskamp MM, De Gruyter J, Crous PW. 2008 - Biology and recent developments in the systematics of Phoma, a complex genus of major quarantine significance. Fungal Diversity $31,1-18$. 
Baun S, Sieber NT, Schworzy FWMR. Fink C. 2003 - Latent infection of Fomes fomentarius in the xylem of European beech (Fagus sylvatica). Mycological Progress 2, 141-148.

Bills GF, Polishook JD. 1992 - Recovery of endophytic fungi from Chamaecyparis thyoides. Sydowia 44, 1-12.

Boddy L, Griffith GS. 1989 - Role of endophytes and latent invasion in the development of decay communities in sapwood of angiospermous trees. Sydowia 41, 41-73.

Bussaban B, Lumyong S, Lumyong P, McKenzie EHC, Hyde KD. 2001 - Endophytic fungi from Amomum siamense. Canadian Journal of Microbiology 47(10), 943-948.

Chareprasert C, Piapukiew J, Thienhirun S, Whalley AJS, Sihanonth P. 2006 - Endophytic fungi of teak leafs Tectona grandis L. and rain tree leafs Samanea saman Merr. World Journal of Microbiology and Biotechnology 22, 481-486.

Cohen SD. $2004 \quad$ - Endophytic-host selectivity of Discula umbrinella on Quercus alba and Quercus rubra characterized by infection, pathogenicity and mycelia compatibility. European Journal of Plant Pathology 110, 713-721.

Cohen SD. 2006 - Host selectivity and genetic variation of Discula umbrinella isolates from two oak species: analyses of intergenic spacer region sequences of ribosomal DNA. Microbial Ecology 52, 463-469.

Dobranic JK, Johnson JA, Alikhan QR. 1995 - Isolation of endophytic fungi from eastern larch (Larix laricina) leaves from New Brunswick, Canada. Canadian Journal of Microbiology 41, 194-198.

Dreyfuss M, Petrini O. 1984 - Further investigations on the occurrence and distribution of endophytic fungi in tropical plants. Botanica Helvetica 94, 33-40.

Ellis MB. 1971 - Dematiaceous Hyphomycetes. CMI, Kew, Surrey, England. p. 608.

Firakova S, Sturdikova M, Muckova M. 2007 - Bioactive secondary metabolites produced by microorganisms associated with plants. Biologia 62, 251-257.

Fisher PJ, Petrini O. 1987 - Location of fungal endophytes in tissues of Suaeda fructicosa: a preliminary study. Transactions of the British Mycological Society 89, 246-249.

Fisher PJ, Petrini O, Sutton BC. 1993 - A comparative study of fungal endophytes in leaves, xylem and bark of Eucalyptus nitens in Australia and England. Sydowia 45, 338-345.

Frohlich J, Hyde KD. 1999 - Biodiversity of palm fungi in the tropics: are global fungal diversity estimates realistic? Biodiversity and Conservation 8, 977-1004.

Goveas SW, Madtha R, Nivas SK, Souza LD. 2011 - Isolation of endophytic fungi from Coscinium fenestratum - a red listed endangered medicinal plant. Eurasian Journal of Biosciences 5, $48-53$.

Guba EF. 1961 - Monograph of Pestalotia and Monochaetia. Harvard University Press, Cambridge, Massachusetts. pp. 342.

Hata K, Futai K. 1995 - Endophytic fungi associated with healthy pine needles and needles infested by the pine needle gall midge, Thecoliphosis japonensis. Canadian Journal of Botany 73, 384-390.

Huang WY, Cai YZ, Hyde KD, Croke H, Sun M. 2008 - Biodiversity of endophytic fungi associated with 29 traditional Chinese medicinal plants. Fungal Diversity 33, 61-75.

Hyde K, Soytong K. 2007 - Understanding microfungal diversity-a critique. Cryptogamie Mycologie 28(4), 1-9.

Hyde KD. 2001 - Increasing the likelihood of novel compound discovery from fungi. In: BioExploitation of Filamentous Fungi. S.B. Pointing, K.D. Hyde (eds) (Fungal Diversity Research Series No. 6) Fungal Diversity Press, Hong Kong. pp 77-91.

Jayanthi G, Kamalraj S, Karthikeyan K, Muthumary J. 2011 - Antimicrobial and antioxidant activity of the endophytic fungus Phomopsis sp. GJJM07 isolated from Mesua ferrea. International journal of Current Science 1, 85-90.

Khan R, Shahzad S, Choudhary MI, Shakeel A. Khan SK, Ahmad A. 2007 - Biodiversity of the endophytic fungi isolated from Calotropis procera (Ait.) R. Br. Pakistan Journal of Botany 39(6), 2233-2239. 
Krishnamurthy YL, Shankar NB, Shashikala J. 2008 - Fungal communities in herbaceous medicinal plants, Malnad region, Southern India. Microbes and Environment 23, 24-28.

Kumar DSS, Hyde KD. 2004 - Biodiversity and tissue-recurrence of endophytic fungi in Tripterygium wilfordii. Fungal Diversity 17, 69-90.

Muller MM, Hallaksela AM. 1998 - Diversity of Norway spruce needle endophytes in various mixed and pure Norway spruce stands. Mycological Research 102, 1183-1189.

Muthumary J, Sashirekha S. 2007 - Detection of taxol, an anticancer drug from selected coelomycetous fungi. Indian Journal of Science and Technology 1, 1-10.

Nag Raj TR. 1993 - Coelomycetous anamorphs with appendage bearing conidia. Mycologue Publications, Waterloo, Ontario, Canada.

Onions A, Allosopp MS, Eggins D. 1981 - Smith's introduction to industrial mycology, $7^{\text {th }}$ edn. Arnold, London, p. 398.

Oses R, Valenzuela S, Freer J, Sanfuentes E, Rodríguez J. 2008 - Fungal endophytes in xylem of healthy Chilean trees and their possible role in early wood decay. Fungal Diversity 33, 7786.

Petrini O. 1986 - Taxonomy of endophytic fungi of aerial plant tissues. In: Microbiology of the Phyllosphere, Fokkema NJ, Heuvel JVD (Eds.) Cambridge University Press Cambridge MA, pp. 175-187.

Qi F, Jing T, Zhan Y. 2012 - Characterization of endophytic fungi from Acer ginnala Maxim. in an artificial plantation: media effect and tissue-dependent variation. PLoS ONE 7(10), e46785.

Raviraja NS. 2005 - Fungal endophytes in five medicinal plant species from Kudremukh Range, Western Ghats of India. Journal of Basic Microbiology 45, 230-235.

Shenoy BD, Jeewon R, Hyde KD. 2007 - Impact of DNA sequence-data on the taxonomy of anamorphic fungi. Fungal Diversity 26, 1-54.

Strobel G, Daisy B. 2003 - Bioprospecting for microbial endophytes and their natural products. Microbiology and Molecular Biology Reviews 67, 491-502.

Strobel GA. 2002a - Microbial gifts from rain forests. Canadian Journal of Plant Pathology 24, 1420.

Strobel GA. 2002b - Useful products from rainforest microorganisms. Part 2. Unique bioactive molecules from endophytes. Agro Food Industry Hi-Tech 13, 12-17.

Strobel GA. 2003 - Endophytes as sources of bioactive products. Microbes and Infection 5(6), 535-544.

Suryanarayanan TS, Murali TS, Venkatesan G. 2002 - Occurrence and distribution of fungal endophytes in tropical forests across a rainfall gradient. Canadian Journal of Botany 80 , 818-826.

Suryanarayanan TS, Murali TS, Venkatesan G. 2003 - Endophytic fungal communities in leaves of tropical forest trees: diversity and distribution patterns. Current Science 85, 489-493.

Suryanarayanan TS, Thennarasan S. 2004 - Temporal variation in endophyte assemblages of Plumeria rubra leaves. Fungal Diversity 15, 197-204.

Sutton BC. 1973a - Coelomycetes. In: The fungi. G.C. Ainsworth, F.K. Sparrow and A.S. Sussman (eds) Volume IV. pp. 513-582.

Sutton BC. 1973b - Hyphomycetes from Manitoba and Saskatchewan, Canadian Mycological Papers 132, 1-143.

Sutton BC. 1980 - The Coelomycetes. Fungi Imperfecti with pycnidia, acervuli and stromata. Commonwealth Mycological Institute, Kew, Surrey, England, p. 696.

Thalavaipandian A, Ramesh V, Bagyalakshmi, Muthuramkumar S, Rajendran A. 2011 - Diversity of fungal endophytes in medicinal plants of Courtallam hills, Western Ghats, India. Mycosphere 2(5), 575-582.

Wang J, Li G, Lu H, Zheng Z, Huang Y, Su W. 2000 - Taxol from Tubercularia sp. strain TF5, an endophytic fungus of Taxus mairei. FEMS Microbiology Letters 193, 249-253. 
Wipornpan P, Saisamorn L, Pipob L, Kevin DH. 2001 - Endophytic fungi of wild banana (Musa acuminata) at Doi Suthep Pui National Park, Thailand. Mycological Research 105, 1508-1513.

Yuan JI, Jian-Nan BI, Bing Y, Xu-Dong Z. 2006 - Taxol producing fungi: a new approach to industrial production of taxol. Chinese Journal of Biotechnology 22, 1-6.

Zhang HW, Song YC, Tan RX. 2006 - Biology and chemistry of endophytes. Natural Product Reports 23, 753-771.

Zhou DP, Sun JQ, Yu HY, Ping WX, Zheng XQ 2001 - Nodulisporium, a genus new to China. Mycosystema 2, 277-278. 